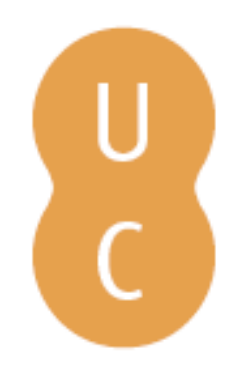

\title{
pompalina
}

\section{Socrates' in Maximus of Tyre, Apuleius, and Plutarch}

\author{
Autor(es): Roskam, Geert
}

Publicado por: Centro de Estudos Clássicos e Humanísticos; Imprensa da Universidade

URL

persistente: URI:http://hdl.handle.net/10316.2/31667

DOI: $\quad$ DOI:http://dx.doi.org/10.14195/978-989-8281-53-1_8

Accessed : $\quad$ 26-Apr-2023 10:44:23

A navegação consulta e descarregamento dos títulos inseridos nas Bibliotecas Digitais UC Digitalis, UC Pombalina e UC Impactum, pressupõem a aceitação plena e sem reservas dos Termos e Condições de Uso destas Bibliotecas Digitais, disponíveis em https://digitalis.uc.pt/pt-pt/termos.

Conforme exposto nos referidos Termos e Condições de Uso, o descarregamento de títulos de acesso restrito requer uma licença válida de autorização devendo o utilizador aceder ao(s) documento(s) a partir de um endereço de IP da instituição detentora da supramencionada licença.

Ao utilizador é apenas permitido o descarregamento para uso pessoal, pelo que o emprego do(s) título(s) descarregado(s) para outro fim, designadamente comercial, carece de autorização do respetivo autor ou editor da obra.

Na medida em que todas as obras da UC Digitalis se encontram protegidas pelo Código do Direito de Autor e Direitos Conexos e demais legislação aplicável, toda a cópia, parcial ou total, deste documento, nos casos em que é legalmente admitida, deverá conter ou fazer-se acompanhar por este aviso.

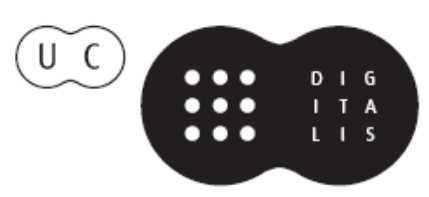




\section{Tychè et Pronoia}

\section{La marche du monde selon Plutarque}

Françoise Frazier et Delfim F. Leão (eds.)

IMPRENSA DA UNIVERSIDADE DE COIMBRA
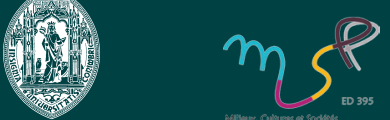


\title{
Socrates' $\delta$ aluóviov in MaXimus of \\ Tyre, Apuleius, and Plutarch
}

\author{
Geert Roskam \\ K. U. Leuven
}

\begin{abstract}
This paper deals with the positions of three Middle Platonists towards Socrates' divine sign.

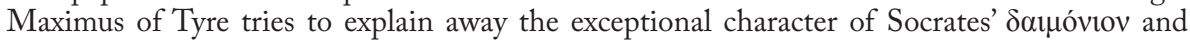
hardly deals with the interaction between the philosopher and his divine sign. Apuleius' general demonology is much more systematic, yet his more particular interpretation of Socrates' $\delta a 1 \mu o ́ v ı v$ hardly surpasses Maximus' views. Plutarch's interpretation in De genio Socratis, on the other hand, is more interesting from a philosophical perspective, as is shown by an analysis of the fundamental interpretations proposed by different speakers in this dialogue.
\end{abstract}

\section{A remarkable case of demonic providence}

Should a philosopher be extravagant? This frank opening question may come as a surprise, certainly among a contemporary, philosophically minded audience. Of course not: why should he? A man's capacities and credibility as a philosopher obviously do not depend on outward idiosyncracies. An educated audience of the second century $\mathrm{AD}$, however, may have been a little less surprised. More than one self-proclaimed philosopher seems to have based his claims primarily on his extravagant looks (esp. the notorious threadbare cloak or $\left.\tau \rho^{\prime} \beta \omega v\right)$ and behaviour (e.g. his disdain for, and harsh insults against everyone he encountered), which, of course, prompted others to unmask such unfounded imposture and self-display ${ }^{1}$.

Should a philosopher, then, perhaps be a man of paradoxes and/or oversophisticated logical quibbles? Again, why should he? Yet again, in antiquity, many younger students were presumably attracted by precisely this aspect ${ }^{2}$, and it is well known that the Stoics liked to express some of their basic doctrines in pithy paradoxes ${ }^{3}$.Other philosophical schools, however, were often less enthusiastic about such paradoxes ${ }^{4}$. Plutarch, for instance, repeatedly blames the Stoics for their $\pi \alpha \rho \alpha \delta o \xi o \lambda o \gamma i \alpha^{5}$, and in De facie, Lamprias argues

${ }^{1}$ Cf., e.g., Plutarch, De prof. in virt. 82B; De Is. et Os. 352C; Dio Cassius, 6,13,1a; Lucian, Pisc. 31 and 46; Bis acc. 6-7; Epictetus, 4,8,4-9, 15 and 34; Athenaeus, 5, 211de; Aulus Gellius, 9,2,4; cf. already Plato, $A$ p. 29 de.

${ }^{2}$ See, e.g., Plutarch, De prof. in virt. 78EF; cf. De aud. 43AB.

${ }^{3}$ While adding, though, that such doctrines had nothing paradoxical for the sage (Diogenes Laertius, 7,123).

${ }^{4}$ Cf., e.g., Cicero, ac. 2,136.

${ }^{5}$ See, e.g., De facie 924A and CD; De comm. not. 1060B; 1068B; 1071D; cf. De Stoic.

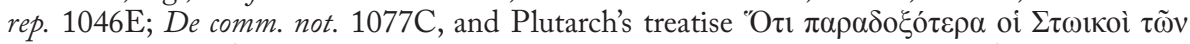

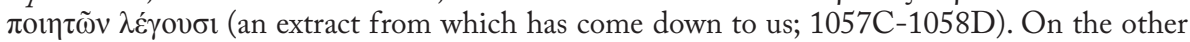
hand, Plutarch realises that his own interpretation of Plato's Timaeus also contains paradoxical elements, which he wants to justify (De an. procr. 1014A). 
that one should not listen to philosophers who wish to ward off paradoxes by means of other paradoxes ${ }^{6}$.

However that may be, there can hardly be any doubt that Socrates was remembered as both an extravagant philosopher and a man of paradoxes. A particularly salient illustration of both these aspects can be found in his

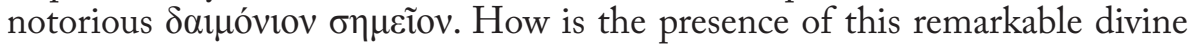
sign to be explained in a man who in every situation only relied on his sober reason $^{7}$ and who was especially interested in human issues, being the first, in Cicero's famous formulation, to call philosophy down from heaven in order to place it in the cities and houses of men ${ }^{8}$ ? Even during Socrates' lifetime, the strange phenomenon was presumably widely discussed in Athens ${ }^{9}$, and when the divine voice was finally silenced by the philosopher's execution, it was not forgotten by Socrates' followers. Plato and Xenophon ${ }^{10}$, but also other "Socratic" philosophers ${ }^{11}$ and Plato's disciples ${ }^{12}$ gave much attention to the divine sign in their writings. The period of so-called Middle Platonism saw a revival of interest in the issue ${ }^{13}$, and also in Neoplatonism, the topic received attention $^{14}$.

The reason for this age-long interest cannot only be found in the remarkable idiosyncrasy of the famous philosopher. For one can easily think of behaviour or claims of other illustrious thinkers that were even more remarkable and yet received far less attention. Empedocles, for instance, was clothed in purple and gold, and used shoes of bronze and a Delphic wreath ${ }^{15}$. Pythagoras would have showed more than once his striking prophetic skills, but several of these

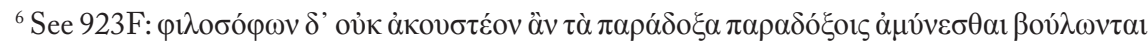
$\kappa \tau \lambda$.

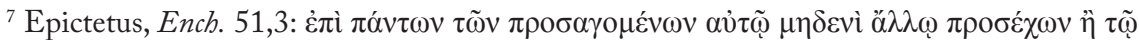
$\lambda$ ó $\omega$; Plutarch, De genio Socr. 580C; cf. already Plato, Cri. 46b.

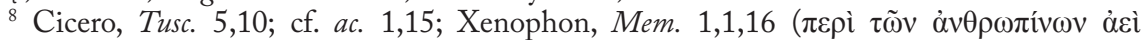
$\delta 1 \varepsilon \lambda \varepsilon \dot{\gamma \varepsilon \tau o) ; ~ c f . ~ a l s o ~ t h e ~ e v e n ~ s t r o n g e r ~ c l a i m ~ i n ~ P l u t a r c h, ~ D e ~ g e n i o ~ S o c r . ~ 582 B: ~ \varphi ı \lambda o б o p i ́ \alpha v ~}$ $\dot{\varepsilon} \xi \alpha v \theta \rho \omega \pi \dot{\sigma} \alpha \alpha \tau \tau$ ○.

${ }^{9}$ Cf. Plutarch, De genio Socr. 581E; Nic. 13,6. This would later enable Meletus, Anytus, and Lycon to charge Socrates for introducing new $\delta \alpha \mu$ óvia (cf. Plato, Ap. 24c and 31cd; Xenophon, Mem. 1,1,1; Diogenes Laertius, 2,40).

${ }^{10}$ A convenient survey of relevant passages can already be found in R.E. Macnaghten (1914); see further M. Joyal (2000), 65-71. On Plato, see also the thorough discussions of H. Gundert (1954); M.L. McPherran (1996), 185-208; Th.C. Brickhouse - N.D. Smith (2000), 244-252.

${ }^{11}$ Cicero, div. 1,122.

12 On the date of composition of the Theages, see M. Joyal (2000), 135-155 (arguing for 345-335 B.C.); on its discussion of Socrates' Saınóviov, see Id. (2000), 72-97. On Xenocrates' demonology in general, see, e.g., J. Dillon (2003), 129-131 and 146-147.

${ }^{13}$ Although it should be noted that our picture may be distorted due to the loss of so many important texts. It cannot be excluded, then, that in the intermediate period Socrates' $\delta \alpha \mu$ óviov was also discussed, e.g. in the context of philosophical debates about divination (cf. Cicero, div. 1,122-124), or in Epicurean attacks against Socrates' supposed $\alpha \lambda \alpha \zeta o v \varepsilon i ́ \alpha$ (cf., e.g., Plutarch, Quaest. Plat. 999C; J. Opsomer (1998), 128).

${ }^{14}$ Proclus, in Alc. 78.8-85.17; Olympiodorus, in Alc. 21.1-14; Hermias, in Phdr. p. 65.2669.31 Couvr.

${ }^{15}$ Diogenes Laertius, 8,73; Aelian, VH 12,32. 
achievements have only come down to us through a few late biographies ${ }^{16}$.

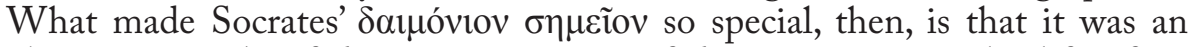
obvious example of direct intervention of divine powers in the life of an individual. Educated Athenians were familiar with such interventions from the Homeric epic literature ${ }^{17}$ and from tragedy (with the deus ex machina as the most tangible example), to be sure, but in Socrates' case, the god(s) seemed to interact with a human being no longer in myths and literature but in real life. In this - admittedly quite extraordinary - individual, the gap between the divine world and that of human beings appeared to be bridged to a certain extent. The gods' providential care for men had no longer to be derived from the general teleological character of nature, nor from prophetic dreams, oracles, and so on, but was illustrated in one particular person. Furthermore, the positive results of this divine guidance were impressive, fascinating, and undeniable: the divine sign enabled Socrates not merely to predict the débâcle of the Sicilian expedition ${ }^{18}$ or to avoid a herd of dirty swine ${ }^{19}$, but even saved his life in the battle of Delium ${ }^{20}$.

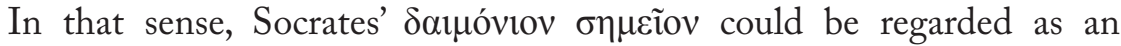
interesting example of the active influence of divine providence in the life of a single individual. In later Platonic school doctrine, however, this fairly general conclusion was made more specific, through an attempt to distinguish between several levels of providence. In the interesting treatise De fato, for instance, which was transmitted under Plutarch's name but was in all likelihood not written by him ${ }^{21}$, a distinction can be found between three different providences, connected with three different levels in the divine realm. On the basis of a few passages in Plato, the author argues that the intellection or will of the highest god should be regarded as primary providence, whereas secondary providence belongs to secondary gods (the stars and planets) and tertiary providence to daemons ${ }^{22}$, and that primary providence includes fate, tertiary providence is included by fate, and secondary providence exists side by side with fate ${ }^{23}$. The details of this theory need not detain us here. What is important for our purpose

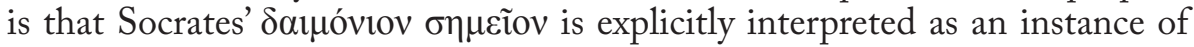
tertiary providence, which yields immediate results that conform to fate ${ }^{24}$. The

${ }^{16}$ Porphyry, VP 25, 28 and 29; Iamblich, VP 28. On the other hand, Pythagoras' notorious claim that he could remember his previous lives was often mentioned in ancient literature; see E. Rhode (1925), II, 417-421.

${ }^{17}$ Maximus of Tyre (8,5a) and Apuleius (Socr. 145) both refer to the famous scene in the first book of the Iliad (1,194-198), where Achilles, who intended to kill Agamemnon, was restrained by Athena. Cf. also Plutarch, De genio Socr. 580CD, who refers to Homer, Od. 13,301.

${ }_{18}^{18}$ Ps.-Plato, Thg. 129cd; Plutarch, De genio Socr. 581D; Nic. 13,6; Alc. 17,4.

${ }^{19}$ Plutarch, De genio Socr. 580D-F.

${ }^{20}$ Plutarch, De genio Socr. 581DE; Cicero, div. 1,123; Epist. Socr. 1,9.

${ }^{21}$ The question of the (in)authenticity of the work has often been examined; see E. Valgiglio (1993), 34-42 for a recent thorough discussion.

${ }_{22}$ Ps.-Plutarch, De fato 572F-574A.

${ }^{23}$ Ibid. 574B-D.

${ }^{24} \mathrm{Ibid}$. 574BC, with reference to Ps.-Plato, Thg. $129 \mathrm{e}$. 
parallels that can be found in other authors ${ }^{25}$ show that this strange theory belongs to the period of Middle Platonism ${ }^{26}$ and drew its main inspiration from a Platonic perspective ${ }^{27}$. It is a typical example of a formalised school doctrine which tries to introduce everything, including even highly personal phenomena such as Socrates' divine sign, into a systematic and hierarchical Platonic world view.

Interesting though such attempts at systematisation may be, they are often bought at the price of oversimplification and neglect of particularities. In this case, too, the theory does not provide any further information about the concrete way in which the tertiary, "demonic" providence precisely worked in Socrates' case. In order to find an answer to this question, one should turn to other sources, more precisely to two speeches of Maximus of Tyre (or. 8 and 9), to Apuleius' De deo Socratis, and to Plutarch's De genio Socratis. In none of these texts is the above mentioned doctrine of the three providences explicitly discussed (although we can be sure that at least Apuleius was familiar with $\mathrm{it}^{28}$ ). Instead, they focus on the providential working of demons in general,

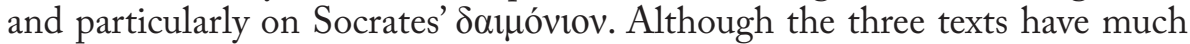
in common, they also show several significant differences. In fact, the three authors took up the topic at issue in a variety of ways, for a variety of audiences, and for a variety of exegetic purposes.

\section{Maximus of Tyre}

The point of departure of Maximus of Tyre's two speeches about Socrates' $\delta a \mu$ óviov is the audience's supposed astonishment ${ }^{29}$ at Socrates' possession of a divine sign. By means of a first lengthy series of concrete examples - Laconic brevity was not one of his qualities -, Maximus then attempts to demonstrate that such phenomenon is not so remarkable after all: if all kinds of people can indeed through many oracles make contact with the demonic realm, a pure and virtuous philosopher such like Socrates is a fortiori able to keep in touch with a $\delta \alpha \mu$ óviov, even on a more individual basis ${ }^{30}$. At the end of his first speech, Maximus even suggests that Socrates was not the only famous thinker who could benefit from such an association with a $\delta \alpha i ́ \mu \omega v$ : Plato too, and Pythagoras, and Zeno and Diogenes all had their personal daemonic supervisor ${ }^{31}$. And through his passing remark that the daemons order him to

${ }^{25}$ Apuleius, de Plat. 1,12 p. 205-206; Nemesius, Nat. hom. 43, p. 125.21-126.12 Morani; cf. Chalcidius, comm. 146.

${ }^{26}$ See further A. Gercke (1886), 284-286; J. Beaujeu (1973), 273-274; J. Dillon (1977), 324-326; S. Gersh (1986), 280-285; R.W. Sharples (2003).

27 P. Moraux (1984), 503-504: “Die Erörterungen über die Vorsehung ( $\pi \rho o ́ v o 1 \alpha)$ und ihr Verhältnis zur Heimarmene stützen sich fast ausschließlich auf platonisches Material, besonders aus dem Timaios. Inhaltlich bieten sie nichts, was auf die aristotelische Tradition zurückzuführen ist."

${ }^{28}$ Cf. supra, n. 25.

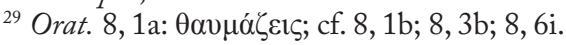

${ }^{30}$ Orat. $8,1 \mathrm{~b}-3 \mathrm{~d}$.

${ }^{31}$ Orat. 8, 8f. 
speak on their behalf ${ }^{32}$, Maximus subtly suggests that he himself can be added to this list of distinguished thinkers. A first important aim of Maximus' speeches, then, consists in explaining away the exceptional character of Socrates' divine sign. The philosopher's $\delta \alpha \mu$ óviov may have been an individual entity ${ }^{33}$, to be sure, but it can perfectly be related to similar phenomena. It should be clear that this argument is not merely a neutral piece of instruction ${ }^{34}$, but that it is also of paramount importance for Maximus' self-presentation. The author indeed presents himself as the competent expert who is able to free his audience from their ignorant amazement. He is the man who, even on such quite obscure and startling issues, can speak from personal experience.

After this piece of indirect self-promotion, Maximus turns to the crucial problem of the precise nature of Socrates' $\delta \alpha \mu$ ovviov $^{35}$, though only to reformulate the question: a correct understanding of this specific instance presupposes an insight into the more general genus of $\delta \alpha \mu$ vova $^{36}$. This is sound methodology, no doubt, which moreover recalls similar Platonic principles ${ }^{37}$, but at the same time, this self-confident methodological strategy enables Maximus to escape embarrassing difficulties: the particularly complex problem of Socrates'strange $\delta \alpha \mu$ óviov can now be replaced by the much less demanding topic of demonology in general ${ }^{38}$. This, apparently, is a subject that better suits Maximus' rhetorical talents. After a lengthy discussion of Homer's treatment of daemons $s^{39}$, which once again helps in explaining away the exceptional nature of Socrates' divine sign (and helps to show how traditional religion is to be understood from a philosophical point of view), Maximus finally begins to develop his views on a hierarchic universe, governed by a benevolent deity who is assisted by secondary immortal beings, the daemons. These daemons occupy an intermediate position, sharing their immortality with the god and their susceptibility to passions with human beings, and thus act as a kind of interpreters between both levels ${ }^{40}$. More precisely, daemons are disembodied souls who, out of pity for kindred souls which are still linked to the body and in accordance with the god's command, involve in human matters ${ }^{41}$. In that sense, and in spite of the fact that Maximus never uses the term $\pi \rho$ óvor $\alpha$ in this

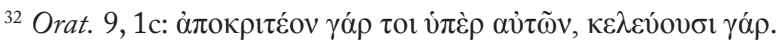

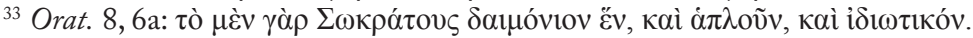

${ }^{34}$ That Maximus' speeches are primarily addressed to the young is argued by G.L. Koniaris (1982), 113-114 and M.B. Trapp (1997), xx-xxii.

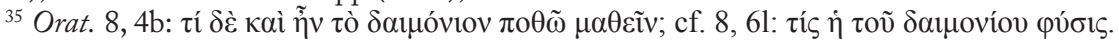

${ }^{36}$ Orat. 8, 4bc; cf. 61 .

${ }^{37}$ Cf., e.g., Meno 71ab. That Maximus' two discourses reflect a Platonic perspective is argued by J. Puiggali (1983), 192-240.

${ }^{38}$ It should be noted, however, that we do not know what title(s) these two lectures were delivered and/or published under. It is not impossible that the original titles promised an account of daimones rather than an explanation of the Socratic daimonion. If that is true, Maximus uses the well-known individual case of Socrates as an effective and striking point of entry to an exposition of an important area of philosophical cosmology and theology.

${ }^{39}$ Orat. 8, 5a-61.

${ }^{40}$ Orat. 8, 8a-9, 4e.

${ }^{41}$ Orat. 9, 6a-g. 
context, these daemons obviously contribute to the highest god's providential care for the world of human beings.

While this general, and fairly superficial perspective is rhetorically elaborated with many examples and parallels ${ }^{42}$, the knotty problem of the

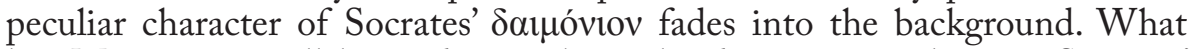
has Maximus to tell his audience about the daemonic working in Socrates' particular case? How should the interaction between Socrates and his $\delta \alpha \mu$ óviov be understood? On this point, Maximus' verbosity conceals a remarkable lack of ideas. His arguments can be reduced to two basic observations. First of all, he more than once underlines Socrates' exceptional purity ${ }^{43}$, which serves both as an a fortiori argument ("if other people, then a fortiori Socrates") and a conditio sine qua non (daemons only assist virtuous people ${ }^{44}$ ), without, however, explaining the individual nature of the phenomenon. Secondly, throughout the two speeches, Maximus is particularly vague about the precise way in which the $\delta a \mu$ óviov communicated with Socrates. At the very outset of the first speech, he merely asserts that the $\delta \alpha \mu$ óviov always "attended" Socrates and was "all but mixed up with his mind" 45 , without further even clarifying whether the Saluóviov had its seat in the body ${ }^{46}$, the soul ${ }^{47}$, or the mind. Socrates' association with the $\delta \alpha \mu$ óviov, or vice versa, is usually described with the

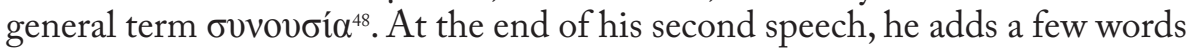
about the visual perception of daemons ${ }^{49}$, and Maximus would not have been Maximus if he would not have pointed out that he himself had seen several of them, not in a dream but in waking reality ${ }^{50}$. One could of course wonder what all this has to do with the divine voice that Socrates could apparently perceive. The less educated members of Maximus' audience may perhaps have been greatly impressed by the sophist's grand finale, but more erudite listeners probably recalled that Socrates used to regard men who claimed to have had visual communication with the divine as boastful charlatans ${ }^{51}$. Was Maximus an $\dot{\alpha} \lambda \dot{\alpha} \zeta \omega v$ ?

I think he was, though a brilliant one! In both speeches, he used traditional material in order to present himself as a virtuoso speaker. His goal is not

${ }^{42}$ Cf. M.B. Trapp (1997), 68: “Maximus' discussion provides the fullest surviving development of the notion that daimones are an indispensable rung in the hierarchy of living beings in the cosmos, but otherwise contains nothing not amply paralleled in the other sources, and at several points side-steps difficulties or refinements which they take into account."

${ }^{43}$ Orat. 8, 1a; 8, 3b; 8, 4a; 8, 6i-1.

${ }^{44}$ Orat. 8, 8g.

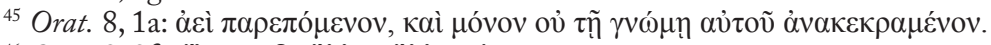

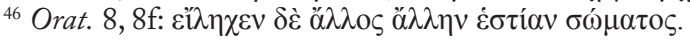

${ }^{47}$ Orat. $8,8 \mathrm{~g}$.

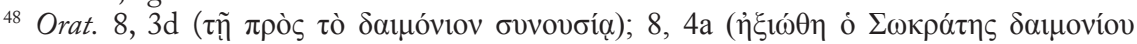

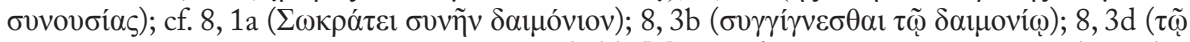

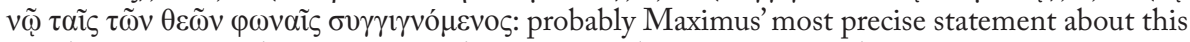

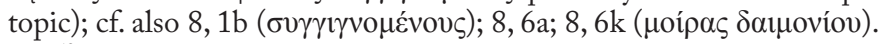

${ }^{49}$ Orat. $9,7 \mathrm{c}-\mathrm{i}$.

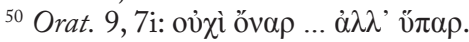

${ }^{51}$ See Plutarch, De genio Socr. 588C. 
so much to provide a systematic exposition of philosophical doctrines, but primarily to impress his audience (by such an exposition). This is $\dot{\pi} \pi \dot{\delta} \delta \varepsilon 1 \xi 1 \varsigma$ aiming at $\pi \varepsilon 1 \theta \omega$ and self-display, rather than a search for the truth. To that purpose, Maximus completely does away with the listeners' initial wonder about Socrates' $\delta \alpha \mu$ óviov and about the tangible influence of the divine world on the life of an individual. And in thus killing wonder, he actually destroys the $\dot{\alpha} \rho \chi \eta$ of philosophy. If there is any place for wonder in the world view which Maximus proclaims, it is wonder about the extraordinary genius of Maximus himself.

\section{Apuleius of Madaura}

The title of Apuleius' speech De deo Socratis is somewhat misleading, since the work is primarily a systematic discussion of demonology. Only a relatively small section is devoted to the particular case of Socrates' $\delta \alpha \mu$ óviov. The work begins $^{52}$ with a reference to Plato's division of the universe into three levels. At the top is the realm of the first god and the lower gods ${ }^{53}$, at the bottom the world of human beings $\mathrm{s}^{54}$, and no direct contact is possible between both ${ }^{55}$. Nevertheless, this gap does not imply that man is entirely left to himself, bereft of any divine help, for there exists an intermediate level of "divine" beings, the daemons, who act as intermediaries between gods and men, and all have their own domain or provincia: dreams, entrails, birds, and so on ${ }^{56}$. Apuleius thus depicts a strongly hierarchical universe, in which all sections have their own function: a kind of perfectly streamlined company, as it were, structured into different departments, administrated by a general manager who is assisted by a series of executive officers. It is clear that this view bears striking resemblance to that of Maximus, and in all likelihood, the view of both authors should directly or indirectly - be traced back to a key passage of Plato's Symposium ${ }^{57}$. Apuleius and Maximus both in their own way draw from their copia verborum in order to elaborate in great detail the Platonic material, but Apuleius' speech is no doubt the more detailed, well considered, and systematic of the two ${ }^{58}$.

That also holds true for the interpretation of the notion of "daemon" itself. Again, Apuleius provides his audience with a systematic division into different categories. A daemon can be both (1) a human mind which is still in the body and (2) a disembodied mind. Moreover, there also exists (3)

${ }^{52}$ On the much-discussed problem of the so-called false preface, see, e.g., V. Hunink (1995); G. Sandy (1997), 192-196; F. Regen (1999), 432-438; S. Harrison (2000), 141-144; M.-L. Lakmann (2004), 23-26.

${ }^{53}$ Socr. $115-124$.

${ }^{54}$ Socr. $125-127$.

55 Socr. 127-132.

${ }^{56}$ Socr. $133-134$.

${ }^{57}$ That is, Smp. 202e-203a.

${ }^{58}$ General studies of Apuleius' demonology include F. Regen (1971); Id. (1999), 451-456; Id. (2000), 41-54; C. Moreschini (1978), 19-27; W. Bernard (1994); P. Habermehl (1996); cf. also S.J. Harrison (2000), 151-161. 
a higher kind of daemons, which have never been linked to the body and act as the individual supervisors of human beings, observing their lives and bringing them to trial after their death ${ }^{59}$. This classification, which is once again a clear-cut systematisation and combination of several isolated ideas in Plato's works ${ }^{60}$, follows upon an extensive discussion of the body of daemons ${ }^{61}$, a characterisation of them as both immortal and susceptible to passions ${ }^{62}$, and a concise, summarising definition ${ }^{63}$.

It is only after this thorough general discussion that Apuleius finally turns to the specific problem of Socrates' $\delta \alpha \mu$ óvıov. Just like Maximus, he begins with an attempt to downplay the extraordinary, exceptional nature of the phenomenon, pointing out that something similar could already be found in Homer ${ }^{64}$. Apuleius' and Maximus' appeal to the supposed surprise of their respective audiences obviously reflects basically the same rhetorical strategy ${ }^{65}$, yet from a more general point of view, their approach is diametrically opposed: whereas Maximus indeed takes the particular case as his starting point for more general reflections, Apuleius only deals with the concrete issue after having elaborated a more general perspective. Although the latter approach makes it easier to explain the phenomenon to an audience that is already introduced to the basics of the Platonic demonology, it is no doubt also the more demanding one, since Apuleius can no longer avoid the more difficult particular questions by escaping towards a more universal perspective. In that sense, Apuleius' challenge is much greater than Maximus'. His answer to it, however, which mainly focuses on two aspects, is almost equally disappointing, at least for philosophically interested listeners ${ }^{66}$.

First, Apuleius deals with the exclusively apotropaic character of Socrates'

${ }^{59}$ Socr. $150-156$.

${ }^{60}$ See, e.g., $P h d .108 \mathrm{~b}$ and $113 \mathrm{~d} ; R$. 620de for the daemon as personal guardian, and Ti 90a

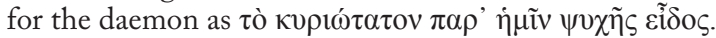

${ }^{61}$ Socr. $140-145$.

${ }^{62}$ Socr. 146-147.

${ }^{63}$ Socr. 148: daemones sunt genere animalia, ingenio rationabilia, animo passiva, corpore aeria, tempore aeterna.

${ }^{64}$ Socr. $158-162$.

${ }^{65}$ According to J. Beaujeu (1973), 240 and S.J. Harrison (2000), 139-140 and 161; Id. (2001), 188, the similarities between Maximus and Apuleius suggest the existence of a common source: "The incredulous rhetorical questions and the stress on the great virtue of Socrates similarly expressed suggest a common origin; both authors are also raising an obvious problem, why the wise Socrates needed a daimonion in the first place, which is likely to have featured in previous writing on the subject." I am not sure whether this is correct: in my view, the similarities are less obvious than Harrison believes - after all, both authors describe Socrates' virtue in very different ways - and may find their origin in basically the same rhetorical strategy, that is, questioning the alleged feelings of the listeners in order to subtly enhance one's own reputation as an erudite, clever speaker. Moreover, both authors do not refer to the audience's surprise that Socrates needed a daimonion, but rather to their wondering about the phenomenon itself (abstracting from the question whether he needed it or not).

${ }_{66}^{6}$ Though perhaps not for Apuleius' listeners; cf. G. Sandy (1997), 211. On the audience of De deo Socratis, see further B.L. Hijmans (1987), 431-433; S.J. Harrison (2001), 187-188; M.-L. Lakmann (2004), 17. 
$\delta a 1 \mu o ́ v ı v$. In his view, the reason why Socrates never received positive advice should be sought in the philosopher's virtuous disposition, which never required positive exhortations but sometimes needed warnings against possible dangers ${ }^{67}$. This is an intelligent suggestion, which recalls Maximus' argument but also surpasses it, in that it uses the traditional element of Socrates' purity not only to explain the presence of the $\delta \alpha \mu$ óviov, but also its general character. On the other hand, Apuleius does not take further advantage of this topic in order to throw more light on the precise nature of the voice or sign that Socrates could perceive.

This crucial question, which directly thematises the communication between god and man, is discussed next, but here, Apuleius' answer is rather disappointing: the voice was not an ordinary one but came from a divine source $^{68}$, as is also indicated by Socrates' claim not just to hear a voice but "a certain kind of" voice ${ }^{69}$. Apuleius thus rejects the interpretation of Socrates' $\delta \alpha \iota \mu o ́ v ı v$ as a kind of ominous chance utterance ( $\kappa \lambda \eta \delta \omega ́ v)$, but only in order to argue - quite remarkably - that Socrates was able to see his strange voice or sign. The basic argument on which this suggestion rests is an argumentum ex auctoritate: the Pythagoreans used to be astonished if anyone claimed that he had never seen a daemon (a testimony the reliability of which is guaranteed by Aristotle, yet another argumentum ex auctoritate) ${ }^{70}$. If all this is true, an easy rhetorical a fortiori argument suffices to make the point: if everyone, then certainly Socrates, the pure sage ${ }^{71}$. In the end, Apuleius thus resembles Maximus both in replacing Socrates' daemonic voice by a visual apparition and by failing to do justice to the exceptional character of Socrates' $\delta \alpha \mu$ óvıov, which becomes a more or less ordinary phenomenon ${ }^{72}$.

In that sense, Apuleius' discussion of the particular nature of Socrates' $\delta \alpha \mu$ óvıov does likewise not surpass the level of a few vague commonplaces. Just like Maximus, Apuleius has to conceal the poverty of his ideas on this issue by means of his brilliant rhetoric. Many question marks are self-confidently replaced by exclamation marks, but behind the façade of rhetorical self-display, many essential questions are left untouched. Apuleius surpasses Maximus, however, in that his rhetoric is coupled with a much more systematic discussion. De deo Socratis happily combines the brilliant rhetoric of the Apology and the Florida with the philosophical

${ }^{67}$ Socr. 162-163. No doubt Socrates was an important model for Apuleius, who may have fashioned his own defence De magia after Plato's Apology; cf. U. Schindel (2000).

${ }^{68}$ Socr. 163: vocem quampiam divinitus exortam; cf. 166: divinitus editam.

${ }^{69}$ Socr. 165: Socrates non vocem sibi, sed vocem quampiam dixit oblatam, which refers to Plato,

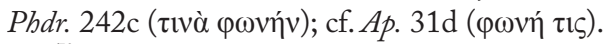

${ }^{70}$ Socr. 166-167.

${ }^{71}$ Socr. 167.

72 S.J. Harrison (2000), 165 correctly notes that Apuleius' "arguments for visual contact between Socrates and his daimonion are weak in the extreme." The reason why Apuleius nevertheless chose to include them can be found, always according to Harrison, in the intellectual context of the work: "The idea of private communion with a god was a highly popular one in the age of the Second Sophistic" (ibid.). 
system of the De Platone, and thus strikingly illustrates both the self-display and the careful philosophical instruction of the self-proclaimed philosophus Platonicus.

\section{Plutarch of Chaeronea}

Plutarch situates his discussion of Socrates' $\delta \alpha \mu$ óvıov in a historical context, viz. the liberation of Thebes in $379 \mathrm{BC}$. This entails a completely

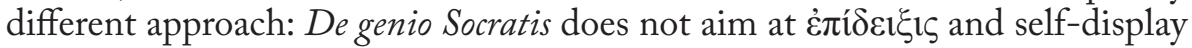
but contains an erudite discussion among philosophically minded conspirators, who are obviously interested in problems of divination. Moreover, the topic of Socrates' divine sign does not come out of the blue, but is the logical consequence of the previous discussions ${ }^{73}$.

The question is raised by Theocritus, as an objection against Galaxidorus, who argued that Socrates was opposed to superstitious beliefs regarding the apparition of divine signs and only relied on sober reasoning ${ }^{74}$. Theocritus' view is fairly superficial ${ }^{75}$ : from his childhood Socrates had a kind of daemonic vision (ö $\psi 1 v$ ) which showed him the way in obscure decisions ${ }^{76}$. It is quite remarkable that it is with regard to this view, which is used by Plutarch in order to introduce the question on a rather general and even somewhat naive level, that several striking parallels can be found with Maximus of Tyre and Apuleius: the mention of Pythagoras, the reference to Athena in Homer, the intervention of the $\delta$ aluóviov in obscure matters, the interest in anecdotes, and, of course, the visual interpretation of the divine voice. Those many significant parallels throw an interesting additional light on the level and scope of Maximus' and Apuleius' discussions. In a certain sense, they do not go (far) beyond a mere introduction of the question. In other words, they stop where Plutarch starts. Their view reflects a pre-philosophical position, and this is precisely the level to which they usually appeal. They are not interested in difficult technical issues, through which they would lose the attention of their audiences. For Plutarch, on the other hand, such pre-philosophical convictions are only the starting point of a more thorough, philosophical inquiry.

The first serious attempt at interpretation comes from Galaxidorus. Briefly, he regards Socrates' $\delta \alpha \mu$ óviov as a trivial external matter, a sneeze or chance

${ }^{73}$ See, e.g., D. Babut (1984), 63-68 on the importance of the theme of divination throughout De genio Socratis. This observation, however, does not solve the complex problem of the unity of De genio Socratis. M. Riley (1977), D. Babut (1984) and A. Georgiadou (1995) regard the relation between vita contemplativa and vita activa as the unifying theme of the work, whereas F.E. Brenk (1996) points to the importance of the theme of freedom, and A. Barigazzi (1988) to the figure of Epameinondas.

${ }^{74}$ De genio Socr. $579 \mathrm{~F}-580 \mathrm{C}$.

${ }^{75}$ And to a certain extent conditioned by the story about Theanor, who spent the night at Lysis' tomb in order to remove the remains and bring it to Italy, unless some $\delta \alpha \mu$ óviov would oppose it

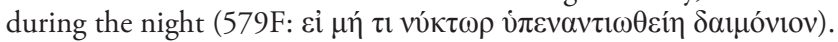

${ }^{76}$ De genio Socr. 580CD. 
remark $(\kappa \lambda \eta \delta \dot{\omega} v)$ which the philosopher used in matters of equipollence ${ }^{77}$. This is a very rationalistic interpretation, which is both in line with Galaxidorus' general view of Socrates and not devoid of important philosophical credentials, as it can be traced back to Socrates' companion Terpsion ${ }^{78}$. It is such an interpretation which is rejected by Apuleius, and Plutarch, too, brings forward several objections. If Socrates was really guided by a sneeze, why then did he not admit this and spoke instead of a divine sign? Is this not evidence of vain affectation? Moreover, the philosopher's behaviour usually seemed to rest on a stable foundation, and anecdotes about the working of the $\delta \alpha \mu$ óviov also seem to point in a different direction ${ }^{79}$. These are interesting counter arguments, and several of them are much more fundamental, at least from a philosophical point of view, than those adduced by Apuleius. But what especially distinguishes Plutarch from Apuleius is the mere fact that he allows Galaxidorus to defend himself. Galaxidorus indeed intelligently argues that Socrates' conduct had nothing to do with conceited affectation: the philosopher realised that the sneeze was merely an instrument of the divinity, and preferred to focus on the divine source rather than on the trivial instrument ${ }^{80}$. This may not be an answer to all problems which Galaxidorus' view entails, to be sure, but the view is interesting enough to be taken into account ${ }^{81}$. It is clear that this is perfectly in line with the dynamics of a philosophical dialogue rather than a rhetorical monologue. The reader is not introduced to ready-made answers, but enters a process of enquiry into the truth ${ }^{82}$.

Then it is Simmias' turn. After having underlined that Socrates' $\delta \alpha \mu$ óviov should be understood as an auditory phenomenon, not a visual one, he elaborates a particularly interesting philosophical alternative, starting from traditional insights about human speech as a blow against the air ${ }^{83}$. In Socrates' case, however, the communication with the daemon did not entail such violent blows, but the philosopher was directly 'touched' in his mind by the daemonic messages ${ }^{84}$. This is not the place to enter at length into the details of Simmias' interpretation ${ }^{85}$, but I would like to emphasise that his approach is completely different from that of Maximus and Apuleius. Simmias' physicalistic interpretation is not based on argumenta ex auctoritate but looks for rational insight, and aims at the truth rather than at $\pi \varepsilon 1 \theta \omega$. Moreover, Simmias does neither try to remove wonder nor explain away the idiosyncratic aspect of

${ }^{77}$ De genio Socr. 580F-581A.

${ }^{78}$ De genio Socr. 581A. On Terpsion, see also Plato, Phd. 59c and Tht. 142a-143c; Suda IV, 404.23 Ad.

${ }^{79}$ De genio Socr. 581B-E.

${ }^{80}$ De genio Socr. $581 \mathrm{~F}-582 \mathrm{C}$.

${ }^{81}$ See esp. D. Babut (1988), who argues that Plutarch never utterly rejects Galaxidorus' point of view, and that such 'rationalism' was one aspect of Plutarch's own philosophical outlook.

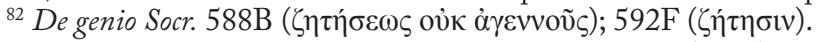

${ }^{83}$ De genio Socr. 588E and 589C; cf. L. Van der Stockt (1992), 57-58.

${ }^{84}$ De genio Socr. 588B-589F.

${ }^{85}$ Good discussions can be found in A. Corlu (1970), 53-60; K. Döring (1984), 379-381; K. Alt (1995), 82-83; A.A. Long (2006). 
Socrates' $\delta$ aluóviov. Socrates is rather depicted as one of the few exceptional men whose outstanding purity enables them to perceive the unuttered messages of daemons ${ }^{86}$. The traditional element of Socrates' perfect virtue is thus used in a particularly interesting way. It does not explain the mere presence of the sign, but is part and parcel of an investigation into the precise way in which the daemon communicated with the human philosopher, and even becomes the interpretative key in order to translate the ordinary theory of language towards the special case of Socrates.

Having developed this view, Simmias goes on to relate what he heard from Timarchus. The core of the latter's view is that the daemon should be equated with the human mind or voṽs, that is, the part of the soul which does not come into contact with the bod $y^{87}$ and which guides - or tries to guide - the soul ${ }^{88}$. From this section on, the specific question of Socrates' $\delta \alpha \mu$ óvıov begins to fade into the background. However, this shift of focus towards a more general perspective is not a clever way to ignore puzzling specific questions. The previous interventions of Galaxidorus and Simmias have already shown that Plutarch, unlike Maximus, does not evade the question of the peculiar nature of Socrates' divine sign. On the other hand, Timarchus' view does not contain a systematically elaborated demonology (such like that of Apuleius) either. What, then, is the function of the Timarchus section within the whole discussion?

First of all, it is important that both at the beginning and at the end, Simmias explicitly characterizes his account as a myth ${ }^{89}$. As such, it can contribute to reaching the truth - $\alpha \lambda \eta \dot{\theta} \theta \varepsilon 1 \alpha$ again, no $\dot{\varepsilon} \pi \hat{\delta} \delta \varepsilon 1 \xi_{1 \zeta}-$, although in a less accurate way than reason ${ }^{90}$. No less important is the actual place of the myth in the discussion. It is not to be found at the beginning of the discussion ${ }^{91}$ but only occurs after reason has first got all the chances to throw its light on the matter. The myth then provides an additional perspective, not

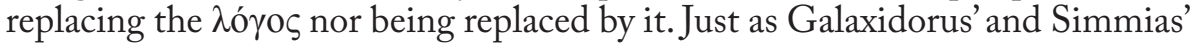
rational, philosophical reflections follow the pre-philosophical convictions of Theocritus, so the myth is only introduced when the philosophical $\lambda$ ó $\gamma$ os has done its work. Such a composition can also be found elsewhere in Plutarch's works ${ }^{92}$, and reflects both his fundamental willingness to rely as much as possible on sober reasoning in his search for the truth and his openness for a complementary perspective. In this, he merely followed the example of his distinguished master Plato himself ${ }^{93}$.

${ }^{86}$ De genio Socr. 588DE and 589C. Socrates was apparently not the only one who attained that level of purity; cf. 592CD on Hermodorus of Clazomenae.

${ }^{87}$ De genio Socr. 591DE.

${ }^{88}$ De genio Socr. 592A-C.

${ }^{89}$ De genio Socr. 589F; 592E and F.

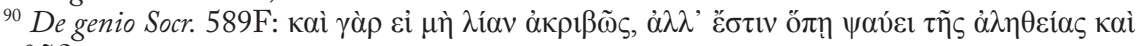
$\tau$ ò $\mu v \theta \tilde{\omega} \delta \varepsilon \varsigma$.

${ }^{91}$ Simmias even hesitates to relate it at all (perhaps $\sigma 1 \omega \pi \tilde{\alpha} v$ is $\alpha$ $\left.\mu \varepsilon เ v o v\right)$, and has to be persuaded by Theocritus; De genio Socr. 589F.

${ }^{92}$ See De facie $937 \mathrm{CD}$ for an interesting parallel example.

${ }^{93}$ The same composition, in which philosophical $\lambda$ ó $\gamma \circ \varsigma$ precedes $\mu \tilde{v} \theta \mathrm{o} \varsigma$, can be found in 
Is there anything to be added after the myth? The last word is for Theanor. He regards daemons as disembodied souls who help kindred souls which are still in the body but which have made much progress and are about to reach the end of the reincarnation process ${ }^{94}$. On the one hand, Theanor recalls several key topics which played an important part in the views of previous speakers, such as the idea of the exceptional nature that is worthy of communication with the gods ${ }^{95}$ or the notion of moral excellence as the conditio sine qua non for the assistance of demons ${ }^{96}$. On the other hand, he also adds a few new elements, the most important of which is that of the daemon as personal supervisor and thus indirectly the providential working of the daemons. This combination of looking back on the previous discussion and introducing a few new ideas shows that Theanor's contribution should be understood as an original evaluative conclusion. This is no mere addendum but the introduction of a broader perspective from which the previous contributions, including both $\lambda$ ó $\gamma \circ$ and $\mu \tilde{v} \theta \mathrm{o} \varsigma$, can be understood ${ }^{97}$. This is also the reason why his contribution has such a general scope: in a retrospective evaluation there is no room for a discussion of particulars, although the introduction of the new perspective can stimulate further thinking. Even after the myth, philosophical reflection can in principle go on. The conspirators, however, do not take this opportunity. For them the time has come to deliver Thebes, for us to conclude.

\section{Conclusion}

In the second half of the fifth century BC, many voices could be heard in Athens. There were the dignified voices of the tragedians, the critical voices of the historians and the humorous voices of the comedians. Sophists discussed with philosophers, politicians with the people, and Socrates with everybody. But in this impressive chorus of usually extremely dissonant, though in some respects also remarkably harmonious voices, there was one strange, divine voice, which never directly took part in the public debates, had perhaps little more to say than a simple and clear "No!" it was this strange voice that became a challenge to later thinking for many ages to come and gave rise to a new chorus of often dissonant voices, three of which were those of Maximus, Apuleius, and Plutarch. Although Socrates' daemonic voice was confined to a brief but crucial period in the history of Western civilisation, at least part of the many voices and the torrents of words which it inspired have come down to us.

\footnotetext{
Plato's Phaedo, Gorgias, and Republic.

${ }^{94}$ De genio Socr. 593A-594A.

${ }^{95}$ De genio Socr. 593D.

${ }^{96}$ De genio Socr. 593F-594A.

${ }^{97}$ Significant in this respect is that Theanor explicitly expresses his approval of both Simmias' and Timarchus' interpretation; De genio Socr. 593A.

${ }^{98}$ Cf. Th.C. Brickhouse - N.D. Smith (2000), 248; contra M.L. McPherran (1996), 204-205.
} 


\section{BibLIOGRAPHY}

Alt, K.(1995), 'Das sokratische Daimonion in der Darstellung Plutarchs', in H. Kessler (ed.), Sokrates. Geschichte, Legende, Spiegelungen. Sokrates-Studien II, Kusterdingen, 71-96.

Babut, D. (1984), 'Le dialogue de Plutarque sur le démon de Socrate.Essai d'interprétation', $B A G B$ 51-76.

- (1988), 'La part du rationalisme dans la religion de Plutarque: l'exemple du De genio Socratis', ICS 13.2,383-407.

Baltes, M. et al. (2004), Apuleius. De deo Socratis.Über den Gott des Sokrates. Eingeleitet, übersetzt und mit interpretierenden Essays versehen von Matthias Baltes, Marie-Luise Lakmann, John M. Dillon, Pierluigi Donini, Ralph Häfner, Lenka Karfíková, Darmstadt (Sapere 7).

Barigazzi, A. (1988), 'Una nuova interpretazione del De genio Socratis', ICS 13.2, 409-425.

Beaujeu, J. (1973), Apulée. Opuscules philosophiques (Du dieu de Socrate, Platon et sa doctrine, Du monde) et fragments. Texte établi, traduit et commenté, Paris (CUF).

Bernard, W. (1994), 'Zur Dämonologie des Apuleius von Madaura', RhM NF 137, 358-373.

Brenk, F.E. (1996), 'Time as Structure in Plutarch'sThe Daimonion of Sokrates', in L. Van der Stockt (ed.), Plutarchea lovaniensia. A Miscellany of Essays on Plutarch, Lovanii, 29-51.

Brickhouse, Th.C. - Smith, N.D. (2000), The Philosophy of Socrates, Boulder.

Corlu, A. (1970), Plutarque. Le démon de Socrate. Texte et traduction avec une introduction et des notes, Paris.

Dillon, J. (1977), The Middle Platonists. A Study of Platonism 80 B.C. to A.D. 220, London.

- (2003), The Heirs of Plato. A Study of the Old Academy (347-274 B.C.), Oxford.

Döring, K. (1984), 'Plutarch und das Daimonion des Sokrates (Plut. de genio Socratis Kap. 20-24)', Mnemosyne 37, 376-392.

Georgiadou, A., (1995), 'Vita activa and vita contemplativa. Plutarch's De genio Socratis and Euripides' Antiope', in I. Gallo - B. Scardigli (eds.), Teoria e prassi politica nelle opere di Plutarco, Napoli, 187-200.

Gercke, A. (1886), 'Eine platonische Quelle des Neuplatonismus', RhM 41, 266-291. 
Gersh, S. (1986), Middle Platonism and Neoplatonism.The Latin Tradition, Notre Dame.

Gundert, H. (1954), 'Platon und das Daimonion des Sokrates', Gymnasium 61, 513-531.

Habermenl, P. (1996), 'Quaedam divinae mediae potestates. Demonology in Apuleius' De deo Socratis', in H. Hofmann - M. Zimmerman (eds.), Groningen Colloquia on the Novel.Volume VII, Groningen, 117-142.

Harrison, S.J. (2000), Apuleius. A Latin Sophist, Oxford.

—- (2001), 'Introduction' [to De deo Socratis], in Id. (ed.), Apuleius. Rhetorical Works. Translated and annotated by S. Harrison, J. Hilton, and V. Hunink, Oxford, 185-194.

Hijmans, B.L. (1987), 'Apuleius, Philosophus Platonicus', in ANRW II.36.1, Berlin - New York, 395-475.

Hunink, V. (1995), 'The Prologue of Apuleius' De deo Socratis', Mnemosyne Ser. IV, 48, 292-312.

Joyal, M. (2000), The Platonic Theages. An Introduction, Commentary and Critical Edition, Stuttgart.

Koniaris, G.L. (1982), 'On Maximus of Tyre: Zetemata (I)', ClasAnt 1, 87121.

Lakmann, M.-L. (2004), 'Einführung in die Schrift', in M. Baltes et al. (2004), 13-44.

Long, A. (2006), 'How does Socrates' divine sign communicate with him?', in S. Ahbel-Rappe - R. Kamtekar (eds.), A Companion to Socrates, Oxford, 63-74.

Macnaghten, R.E. (1914), 'Socrates and the Sauóviov', CR 28, 185-189.

McPherran, M.L. (1996), The Religion of Socrates, University Park PA.

Moraux, P. (1984), Der Aristotelismus bei den Griechen von Andronikosbis Alexander von Aphrodisias. Zweiter Band: Der Aristotelismus im I. und II. Jh. n. Chr., Berlin - New York.

Moreschini, C. (1978), Apuleio e il platonismo, Firenze.

Opsomer, J. (1998), In Search of the Truth. Academic Tendencies in Middle Platonism, Brussel.

Puiggali, J. (1983), Étude sur les Dialexeis de Maxime de Tyr, conférencier platonicien du IIème siècle, Lille.

Regen, F. (1971), Apuleius philosophus Platonicus. Untersuchungen zur Apologie (De magia) und zu De mundo, Berlin - New York. 
_- (1999), 'Il De deo Socratis di Apuleio', Maia 51, 429-456.

- (2000), 'Il De deo Socratis di Apuleio (II parte)', Maia 52, 41-66.

Rhode, E. (1925), Psyche. Seelencult und Unsterblichkeitsglaube der Griechen, Tübingen.

Riley, M.(1977), 'The purpose and unity of Plutarch's De genio Socratis', GRBS $18,257-273$.

Sandy, G. (1997), The Greek World of Apuleius. Apuleius and the Second Sophistic, Leiden - New York - Köln.

Schindel, U. (2000), 'Apuleius - Africanus Socrates? Beobachtungen zu den Verteidigungsreden des Apuleius und des platonischen Sokrates', Hermes 128, 443-456.

Sharples, R.W. (2003), 'Threefold Providence: The History and Background of a Doctrine', in Id. - A.D.R. Sheppard (eds.), Ancient Approaches to Plato's Timaeus, London, 107-127.

Trapp, M.B. (1997), Maximus of Tyre. The Philosophical Orations. Translated, with an Introduction and Notes, Oxford.

Valgiglio, E. (1993), [Plutarco]. Il Fato. Introduzione, testo critico, traduzione e commento, Napoli.

VAn der Stockt, L. (1992), Twinkling and Twilight. Plutarch's Reflections on Literature, Brussel. 